\title{
DENITRIFYING BIOREACTOR WOODCHIP RECHARGE: MEDIA PROPERTIES AFTER NINE YEARS
}

\author{
L. Christianson, G. Feyereisen, C. Hay, U. Tschirner, K. Kult, \\ N. Wickramarathne, N. Hoover, M. Soupir
}

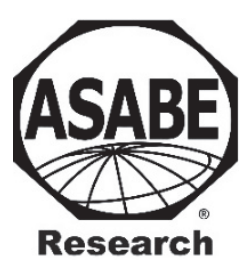

\section{HighLIGHTS}

- Wood media harvested from a nine-year-old denitrifying bioreactor were evaluated.

- Media physical changes had multiple causes and effects.

- Impacts of the physical changes may have been exacerbated by development of preferential flow.

- LCIs $>0.6$ showed $\mathrm{C}$ quality declined but media still supported $\mathrm{N}$ removal.

ABSTRACT. There is a lack of information on denitrifying bioreactors treating subsurface drainage water at the end of their initial design life due to the relative newness of the technology and the relatively long estimated life. A denitrifying bioreactor $(15 \mathrm{~mL} \times 7.6 \mathrm{~m} \mathrm{~W} \times 1.1 \mathrm{~m} \mathrm{D})$ installed in August 2008 in Greene County, Iowa, was recharged with new woodchips in November 2017 (age 9.25 years), providing the opportunity to evaluate the properties of the wood media at the end of design life. The objective was to pair a battery of physical, chemical, and nitrate-N removal tests on the wood media harvested from the bioreactor with field observations to assess likely reasons why denitrifying bioreactors treating tile drainage may need to be recharged. The two types of wood media harvested from the bioreactor (termed woodchips and mixed shreds) had median particle sizes $\left(D_{50}\right)$ of 12.1 and $7.7 \mathrm{~mm}$, respectively, and saturated hydraulic conductivities of $4.2 \pm 3.0$ and 3.1 $\pm 1.0 \mathrm{~cm} \mathrm{~s}^{-1}$ (mean \pm standard deviation), which were within the range of reported values for woodchips, albeit at the low end. The wood media carbon content and quality had degraded (e.g., lignocellulose indices of 0.63 to 0.74, nearing the range of decomposition stabilization), although batch tests suggested the robustness of wood as a carbon source to support nitrate removal (e.g., 65\% nitrate concentration reduction in drainage water). Woodchip degradation along with sedimentation from the drainage system likely reduced conductivities over time. Development of preferential flow paths through the bioreactor was indicated by low bioreactor outflow rates (i.e., reduced permeability) and reduced hydraulic efficiency based on conservative tracer testing. These changes in media properties and linked impacts resulted in the need to recharge this bioreactor after nine years.

Keywords. Denitrifying bioreactor, Hydraulic conductivity, Nitrate, Water quality.

(2) $\Theta \Theta$ The authors have paid for open access for this article. This work is licensed under a Creative Commons AttributionNonCommercial-NoDerivatives 4.0 International License https://creative commons.org/licenses/by-nc-nd/4.0/

Submitted for review in September 2019 as manuscript number NRES 13709; approved for publication as a Research Article by the Natural Resources \& Environmental Systems Community of ASABE in January 2020.

Mention of company or trade names is for description only and does not imply endorsement by the USDA. The USDA is an equal opportunity provider and employer.

The authors are Laura E. Christianson, Assistant Professor, Department of Crop Sciences, University of Illinois, Urbana, Illinois; Gary W. Feyereisen, Agricultural Engineer, USDA-ARS Soil and Water Management Research Unit, St. Paul, Minnesota; Christopher Hay, Senior Manager, Production Systems Innovation, Iowa Soybean Association, Ankeny, Iowa; Ulrike W. Tschirner, Professor, Department of Bioproducts and Biosystems Engineering, University of Minnesota, St. Paul, Minnesota; Keegan Kult, Executive Director, Agricultural Drainage Management Coalition, Ankeny, Iowa; Niranga M. Wickramarathne, Graduate Student, Department of Crop Sciences, University of Illinois, Urbana, Illinois; Natasha Hoover, Research Associate, and Michelle L. Soupir, Associate Professor, Department of Agricultural and Biosystems Engineering, Iowa State University, Ames, Iowa. Corresponding author: Laura E. Christianson, S-322 Turner Hall, M/C 046, University of Illinois, Urbana, IL 61801; phone: 217-244-6173; e-mail: lechris@illinois.edu.

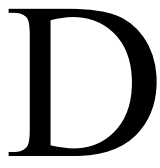
enitrifying bioreactors are a nitrate treatment technology that has moved beyond proof-ofconcept, with demonstration and adoption promoted in agricultural areas around the world (Christianson and Schipper, 2016). Research on these systems has reached a critical mass, with an exponential increase in bioreactor studies over the past ten years (Addy et al., 2016). However, because denitrifying bioreactors, particularly those filled with woodchips for treating subsurface tile drainage, have estimated design lives of approximately 10 to 15 years (USDA, 2015), few field sites have evaluated bioreactor performance at the end of initial design life. Assessment of bioreactor media properties from field-scale bioreactors that have reached this stage may help identify procedures for making timely recharge (i.e., woodchip replacement) decisions as well as refine recommended woodchip standard specifications.

Several aspects of denitrifying bioreactor fill, which is nearly always woodchips, are important for bioreactor functioning. The physical properties, i.e., particle size, porosity, bulk density, and saturated hydraulic conductivity $\left(K_{\text {sat }}\right)$, of 
woodchips are thought to provide sufficient hydraulic capacity for a number of years compared to other media such as straw or corn cobs. Several studies have documented woodchip hydraulic conductivities, which are commonly about $5 \mathrm{~cm} \mathrm{~s}^{-1}$ (Feyereisen and Christianson, 2015), although they range from 2.7 to $12.2 \mathrm{~cm} \mathrm{~s}^{-1}$ for 13 to $20 \mathrm{~mm}$ woodchips (Burbery et al., 2014; Cameron and Schipper, 2010; Chun et al., 2009). Ghane et al. (2014) reported that the hydraulic conductivity of fresh woodchips was significantly greater than that of 26-month-old woodchips ( 8.4 vs. $2.4 \mathrm{~cm} \mathrm{~s}^{-1}$, respectively; initial median diameter of $8.1 \mathrm{~mm})$. Over a similar 22-month period, Cameron and Schipper (2010) found that the $K_{\text {sat }}$ of $15 \mathrm{~mm}$ woodchips decreased from approximately 8.1 to $5.2 \mathrm{~cm} \mathrm{~s}^{-1}$. A denitrifying woodchip bioreactor will remain operational in the field much longer than these studies, and it is not known what the $K_{\text {sat }}$ will be as the bioreactor nears the end of design life nor how changes in $K_{\text {sat }}$ will impact nitrate-removal performance.

The nutrient composition and quality of the wood media will also change during bioreactor functioning due to a variety of processes. The wood of most tree species is generally $47 \%$ to $51 \%$ carbon $(\mathrm{C})$ and less than $0.20 \%$ nitrogen $(\mathrm{N})$ (Martin et al., 2015), meaning that the initial C:N ratio of many types of wood media used in denitrifying bioreactors is initially greater than 200 . Based on the stoichiometry of denitrification, the $\mathrm{C}$ in a woodchip bioreactor is sufficient to last for decades, even considering that it fuels many diverse microbial and fungal communities (Robertson and Cherry, 1995). Regardless, it is well documented that the $\mathrm{C}: \mathrm{N}$ ratio of woodchips declines over time, with several small-scale studies reporting decreases in woodchip C:N from $>250$ to $<180$ in experiments lasting less than one year (Christianson et al., 2016; Feyereisen et al., 2016; Roser et al., 2018). As $\mathrm{C}$ is consumed and the $\mathrm{C}: \mathrm{N}$ ratio declines, the $\mathrm{C}$ quality also changes. The lignocellulose index $(\mathrm{LCI}=$ lig$\mathrm{nin} /$ [ lignin + cellulose]), which ranges from 0 to 1.0 , can be a useful measure of the quality of the remaining $\mathrm{C}$. A greater LCI indicates that a relatively greater percentage of the material is lignin, and thus the material is more recalcitrant to processes such as denitrification. Schmidt and Clark (2012) reported that the LCI of pine sawdust in a denitrifying wall in Florida increased from 0.25 to 0.40 over 540 days.

As denitrifying bioreactors using woody media have matured, the time has arrived to recharge full-size bioreactors after years of documented nitrate removal. While other studies have reported changes in woodchip properties over relatively short times (e.g., 2 to 4 years; Ghane et al., 2018), this study provided the first opportunity to evaluate a fully operational field-scale bioreactor near the end of its initial design life. Moorman et al. (2010) and Robertson (2010) provided the only other similar long-term evaluations of bioreactors treating tile drainage. Moorman et al. (2010) reported that an in-field denitrification wall was capable of supporting denitrification activity and nitrate removal over a nine-year period. Robertson (2010) found that woodchips lost approximately $50 \%$ of their "reactivity" during their first year in a bioreactor, followed by relatively stable $\mathrm{N}$ removal rates over decadal timeframes. In the current study, we hypothesized that the bioreactor did not require recharging due to $\mathrm{C}$ limitation of the $\mathrm{N}$ removal process but rather due to restriction of hydraulic properties. The objective was to pair a battery of physical, chemical, and nitrate-N removal tests on the wood media harvested from the bioreactor with field observations to assess likely reasons why denitrifying bioreactors treating tile drainage may need to be recharged.

\section{Methods ANd Materials SITE DESCRIPTION}

In August 2008, a woodchip bioreactor $(5 \mathrm{~m} \mathrm{~L} \times 7.6 \mathrm{~m} \mathrm{~W}$ $\times 1.1 \mathrm{~m} \mathrm{D}$ ) was installed to treat subsurface drainage water from 19 ha of conventionally managed row crops (Zea mays L. and Glycine max (L.) Merr.) in Greene County, Iowa. This bioreactor is one of the oldest full-size bioreactors treating tile drainage in the peer-reviewed literature (Addy et al., 2016). It was constructed with a mixture of woodchips and wood shreds, as reported by Christianson et al. (2010) (fig. 1), although many initial media properties (e.g., $K_{\text {sat }}$, nutrient composition) were not evaluated. The sides, but not the bottom, of the bioreactor were lined with plastic. This early bioreactor was installed prior to development of the federal conservation practice standard, which recommends using a liner on the bottom and sides (USDA, 2015). During its first three years of operation, the bioreactor treated $51 \%$ to $68 \%$ of the flow (bypassing the remainder) and removed $46 \%$ to $68 \%$ of the nitrate from the water that was treated, resulting in nitrate-N load reductions of $27 \%$ to $33 \%$ at the edge of the field (Christianson et al., 2012b) and removal rates of 7.8, 6.7, and $0.41 \mathrm{~g} \mathrm{~N} \mathrm{~m}^{-3} \mathrm{~d}^{-1}$, with inflow concentrations ranging from approximately 5.0 to $20 \mathrm{mg} \mathrm{NO} 3-\mathrm{N}$ $\mathrm{L}^{-1}$. Later, Jones and Kult (2016) reported that this bioreactor generally removed $50 \%$ of the inflow nitrate- $\mathrm{N}$ load (median value of $6.68 \mathrm{~g} \mathrm{~N} \mathrm{~m}^{-3} \mathrm{~d}^{-1}$ for samples collected from October 2008 to July 2015, not considering bypass flow). Wood media subsidence was observed over the bioreactor's life, particularly near the inlet (estimated at 30 to $60 \mathrm{~cm}$ based on anecdotal observation). Historic weather data were collected from the Jefferson station (Iowa, 2019), which is within $15 \mathrm{~km}$ of the bioreactor. The average annual long-term precipitation at the site was approximately $870 \mathrm{~mm}$ (1981 to 2010 climate normal).

\section{Wood Media Collection}

The bioreactor was recharged with new woodchips on 7 to 8 November 2017 (age 9.25 years) by removing the soil cap with earthwork equipment, excavating the wood media to the inlet tile invert (i.e., elevation of the bottom of the pipe), and relining the entire bioreactor with plastic at that depth. Approximately $0.3 \mathrm{~m}^{3}$ of woodchips and $0.6 \mathrm{~m}^{3}$ of mixed woodchips and wood shreds (termed mixed shreds) were loaded into $1 \mathrm{~m}^{3}$ bulk sacks and transported to St. Paul, Minnesota, for analysis. The mixed shreds were collected near the middle of the bioreactor, whereas the woodchips were excavated closer to the outlet. The use of two types of media (from two different suppliers) was not an intentional design decision but rather a consequence of the relative inexperience with bioreactor design and installation in the early days (i.e., 2008) of bioreactor demonstration efforts. 


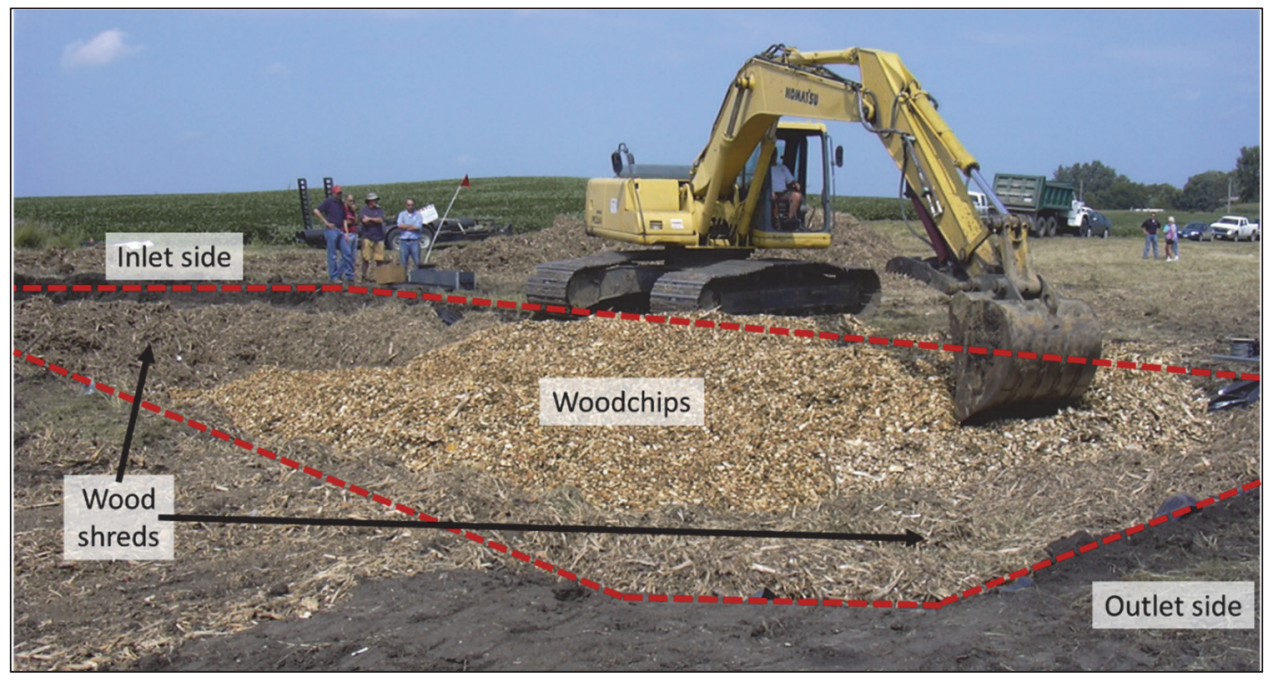

Figure 1. Installation of Greene County, Iowa, bioreactor in August 2008 using two media types: woodchips (concentrated toward the middle) and wood shreds (positioned around the edges). The dashed outline indicates the approximate edges of the excavation.

Because two types of woody media were initially used in this bioreactor (fig. 1), the two post-bioreactor media samples, which differed visually in color and size, were kept separate for analysis.

\section{FLOW AND NitRATE-N REMOVAL ANALYSIS}

Prior to woodchip replacement, field methods generally followed Christianson et al. (2012b) during a monitoring period from 29 March to 4 October 2016. Flow rates were calculated from pressure transducers placed in the bioreactor's control structures along with the appropriate weir equation, and grab samples were collected periodically and analyzed for nitrate- $\mathrm{N}\left(\mathrm{NO}_{3}{ }^{-} \mathrm{N}+\mathrm{NO}_{2}{ }^{-}-\mathrm{N}\right)$ using cadmium reduction (Lachat QuickChem, Loveland, Colo., prior to 2015 and Seal Analytical AQ2, Mequon Wisc., for 2015-2016). Pressure transducers placed in the inlet and outlet control structures were used to calculate the bypass flow and bioreactor outflow rates, respectively. Only flow going over these stop-log weirs was included in the water balance. Total flow from the field and bioreactor inflow are often not monitored at fieldscale bioreactor sites because such monitoring generally requires more expensive instrumentation as well as more elaborate plumbing beyond the structures used to control bioreactor flow. Thus, for many field-scale bioreactors, the total drainage flow from the field is estimated by summing the bioreactor outflow with the bypass flow.

\section{Conservative Tracer Tests}

Conservative tracer tests were performed at the Greene County bioreactor on 7 July 2009 and 28 June 2016 to better understand the internal hydraulics. Concentrated potassium bromide tracer solutions were poured into the inlet control structure as quickly as possible (i.e., in a slug) when no bypass flow was occurring. Water samples were collected from the bioreactor outlet with an auto-sampler (Teledyne ISCO, Lincoln, Neb.). The 2009 samples were analyzed for bromide at Iowa State University (Lachat QuickChem, Loveland, Colo.), and the 2016 samples were analyzed at the USDA-ARS laboratory in Ames, Iowa (Dionex ICS-2000 system using reagent-free ion chromatography with eluent generation).

The mean tracer residence time, or the average length of time required for the tracer solution to move through the reactor, was calculated according to Tchobanoglous et al. (2003). This residence time was compared to the theoretical hydraulic retention time (HRT) at which the bioreactor was operating, which was calculated as the drainable porosity multiplied by the total bioreactor volume (as constructed) divided by the daily bioreactor flow rate. The ratio of tracer residence time to theoretical HRT is referred to as the reactor's effective volume (e). If the tracer solution exits earlier than the theoretical HRT would indicate, the effective volume is less than 1.0, indicating less than ideal use of the reactor volume (Thackston et al., 1987). A hydraulic efficiency metric $(\lambda)$ was calculated by dividing the time at which peak of the tracer solution exited by the theoretical HRT.

\section{HydRaulic Conductivity Tests}

The permeameter apparatus described by Feyereisen and Christianson (2015) and Ghane et al. (2016) was used to determine hydraulic parameters for the post-bioreactor woodchips and mixed shreds (i.e., the nine-year-old harvested media). The $250 \mathrm{~cm}$ long $\times 30 \mathrm{~cm}$ diameter permeameter tube was packed by tamping approximately 11 or 12 layers of $20 \mathrm{~L}$ each of media with a $5.6 \mathrm{~kg}$ tamper dropped from a height of $50 \mathrm{~cm}$. Municipal water was tempered in a $1 \mathrm{~m}^{3}$ universal bulk container prior to the permeameter tube being filled with water from the bottom (i.e., upflow). The woody media were allowed to soak overnight. The following day, a manometer with taps at the inlet and outlet ends of the permeameter was used to determine head loss $(\Delta \mathrm{H})$ at increasing flow rates with the hydraulic gradient $(\Delta \mathrm{H} / \mathrm{L})$ ranging from 0.004 to 0.109 . Flow was measured with a bucket, scale, and stopwatch. Water temperature was recorded from a digital thermometer affixed to the permeameter outlet pipe. At completion of the test, drainable porosity (water drained by gravity) was determined by measuring the water drained 
from the full tube. Hydraulic conductivity was calculated as described by Feyereisen and Christianson (2015).

The sample volume of post-bioreactor mixed shreds collected on-site was sufficient for two hydraulic conductivity replications because of the large volume required to fill the permeameter. Two additional replications were conducted with mixed shreds from the first two runs that had been airdried, mixed, and reused (i.e., pseudo-replications). The sample volume of post-bioreactor woodchips collected onsite was sufficient for one hydraulic conductivity test. A pseudo-replication was performed for the woodchip media with half the material as collected and half recovered from the first test. In total, including pseudo-replications, four tests were performed with the mixed shreds and two tests were performed with the woodchips ( $n=4$ and 2, respectively). Because the saturated conductivity trials included pseudo-replications, no statistical comparisons were made for $K_{\text {sat }}$, packing density, or porosity.

\section{Particle Size Analysis}

Subsamples of approximately $200 \mathrm{~g}$ were collected from each $20 \mathrm{~L}$ bucket of wood media placed into the permeameter tube. The subsamples were composited for every two buckets, e.g., for 12 buckets of wood media there were six samples, and the samples were oven-dried $\left(65^{\circ} \mathrm{C} \pm 5^{\circ} \mathrm{C}, 24\right.$ to $54 \mathrm{~h}$ ) for dry mass determination. The media were then kept at room conditions for one day prior to sieving. Batches of approximately $100 \mathrm{~g}$ of media were sieved $(25,19,12.5$, $9.5,8,6.3,4.75,3.35$, and $1.18 \mathrm{~mm}$ ) for $10 \mathrm{~min}$ (Meinzer II, CSC Scientific Co., Fairfax, Va.). Some samples contained a substantial proportion of mineral soil sediment in the bottom pan $(<1.18 \mathrm{~mm})$.

Particle size analysis for the initial woodchips and wood shreds used during bioreactor installation was performed in a similar manner and was previously reported by Christianson et al. (2010). For all initial and post-bioreactor datasets (i.e., fresh and nine-year-old harvested media, respectively), $\mathrm{D}_{10}$ (effective size, where only $10 \%$ by mass of the sample is of smaller diameter), $\mathrm{D}_{50}$ (median diameter), and uniformity coefficients $\left(\mathrm{UC}=\mathrm{D}_{60} / \mathrm{D}_{10}\right)$ were calculated by interpolation.

\section{Chemical Analysis of Media}

Six subsamples of both types of wood media were ground (1.0 mm mesh) for $\mathrm{C}$ quality and $\mathrm{C}$ and $\mathrm{N}$ concentration analyses. For each subsample, Klason lignin was determined gravimetrically. The concentration of sugars released after acid hydrolysis was determined by high-performance liquid chromatography (model 1525 Binary Pump, Waters Corp., Milford, Mass.) using a prepacked analytical column (Aminex HPX-87P, Bio-Rad, Hercules, Cal.) with a de-ashing cartridge (No. 125-0118, Bio-Rad) in line and a refractive index detector (model 2414, Waters Corp.) at a flow rate of $0.3 \mathrm{~mL} \mathrm{~min}{ }^{-1}$ and $80^{\circ} \mathrm{C}$ column temperature (Sluiter et al., 2012). Ash content via combustion at $550^{\circ} \mathrm{C}$ was determined according to Sluiter et al. (2012). Due to the presence of mineral soil sediment in the woodchip samples, ash contents $>10 \%$ were observed in several samples. To eliminate the impact of potential inorganic carryover, all Klason lignin samples were ashed, and inorganic content was subtracted from the originally determined Klason lignin. Computation of hemicellulose and cellulose took ash content in consideration. Cellulose and hemicellulose were calculated using the equations provided by Ghane et al. (2018). Lignocellulose index (LCI) was calculated as: (Klason lignin) / (Klason lig$\operatorname{nin}+$ cellulose).

Carbon and $\mathrm{N}$ concentrations were analyzed by combustion (vario MAX cube, Elementar, Ronkonkoma, N.Y.). Particles passing through the $1.18 \mathrm{~mm}$ sieve were excluded from the analysis because of the high proportion of mineral soil sediment in this fraction. One-way analysis of variance (ANOVA) was used to compare $\mathrm{C}$ quality components, $\mathrm{LCI}$, $\mathrm{C}$ and $\mathrm{N}$ concentrations, and C:N ratio $(\alpha=0.05$; Sigma Plot 13.0, SYSTAT, San Diego, Cal.).

\section{Nitrate Removal Batch Test}

A subsample of the media sent to St. Paul, Minnesota, for analysis was further transported to Urbana, Illinois, for batch testing to assess the $\mathrm{N}$ removal potential of the post-bioreactor wood media. Four treatments, evaluated in triplicate $(n=$ 3 ), consisted of two types of woodchips (harvested post-bioreactor woodchips and fresh woodchips) and two types of $\mathrm{N}$-dosed water (tile drainage and deionized water). The postbioreactor mixed shreds were not tested in this balanced block design because we thought that the post-bioreactor woodchips would be a more direct comparison with the fresh woodchips. The fresh woodchips used for comparison were a "mixed hardwood blend" obtained from a local woodchip supplier (Corsaw Hardwood Lumber, Ellisville, Ill.) with $\mathrm{D}_{10}, \mathrm{D}_{50}$, and UC of $13.7 \mathrm{~mm}, 21.2 \mathrm{~mm}$, and 1.6, respectively.

Each batch jar contained $10 \mathrm{~g}$ (air-dried weight) of either type of woodchips plus $200 \mathrm{~mL}$ of either type of water that had been dosed to $33.2 \pm 1.30 \mathrm{mg} \mathrm{NO}_{3}-\mathrm{N} \mathrm{L}^{-1}$. The initial nitrate concentration was greater than most tile drainage nitrate samples (e.g., following Hertzberger et al., 2019) but was selected to provide a clear response over the $96 \mathrm{~h}$ test. Neither wood media were inoculated with denitrifying bacteria. The jars were gently swirled upon filling with chips and supernatant $(t=0 \mathrm{~h})$ and then placed in darkness at room temperature $\left(21^{\circ} \mathrm{C}\right)$ until the predetermined sampling events at $0.16,0.5,1,2,4,8,12,24,48$, and $96 \mathrm{~h}$ (10 sampling events $\times 4$ treatments $\times 3$ replicates $=120$ total jars). For each sampling event, the water sample was filtered ( $45 \mu \mathrm{m}$ filter), stored at $4{ }^{\circ} \mathrm{C}$, and analyzed for nitrate-nitrogen $\left(\mathrm{NO}_{3}-\mathrm{N}+\right.$ $\mathrm{NO}_{2}-\mathrm{N}$ ) (Lachat QuickChem, 10-107-04-1-A, Loveland, Colo.). Following the final sampling event, the woodchips were air-dried, stored at $21^{\circ} \mathrm{C}$, and sent to an external lab for nutrient content analysis (Brookside Laboratory, New Bremen, Ohio). One-way ANOVA was used to compare the batch testing results at the final sampling event $(\alpha=0.05$; Sigma Plot 14.0, SYSTAT, San Diego, Cal.).

\section{RESULTS \\ Physical Properties of Media}

The $K_{\text {sat }}$ of the woodchips and mixed shreds were $4.2 \pm 3.0$ and $3.1 \pm 1.0 \mathrm{~cm} \mathrm{~s}^{-1}$ (mean \pm standard deviation), respec- 
Table 1. Mean physical properties of two types of wood media, initial and post-bioreactor, used in the Greene County, Iowa, denitrifying bioreactor. Initial values were either adapted from Christianson et al. (2010), were originally unpublished, or were not measured.

\begin{tabular}{|c|c|c|c|c|c|c|c|}
\hline & & \multicolumn{3}{|c|}{ Particle Size Distribution $^{[\mathrm{a}]}$} & \multirow{2}{*}{$\begin{array}{c}\text { Drainable } \\
\text { Porosity }{ }^{[b]} \\
(\%)\end{array}$} & \multirow{2}{*}{$\begin{array}{c}\text { Bulk } \\
\text { Density } \\
\left(\mathrm{kg} \mathrm{m}^{-3}\right)\end{array}$} & \multirow{2}{*}{$\begin{array}{l}\text { Saturated Hydraulic } \\
\text { Conductivity }{ }^{[b]} \\
\left(K_{\text {sat }}, \mathrm{cm} \mathrm{s}^{-1}\right)\end{array}$} \\
\hline & & $\begin{array}{c}\mathrm{D}_{10} \\
(\mathrm{~mm})\end{array}$ & $\begin{array}{c}\mathrm{D}_{50} \\
(\mathrm{~mm})\end{array}$ & $\mathrm{UC}$ & & & \\
\hline \multirow[t]{2}{*}{ Initial media } & Woodchips & 5.8 & 15.1 & 2.9 & Not measured & 193 & Not measured \\
\hline & Wood shreds & 2.2 & 12.0 & 7.6 & Not measured & 100 & Not measured \\
\hline \multirow[t]{2}{*}{ Post-bioreactor media } & Woodchips & 1.0 & 12.1 & 14 & 33 & 171 & $4.2 \pm 3.1$ \\
\hline & Mixed shreds & 0.7 & 7.7 & 14 & 32 & 194 & $3.1 \pm 1.0$ \\
\hline
\end{tabular}

[a] $\mathrm{D}_{10}=$ effective size, $\mathrm{D}_{50}=$ median diameter, and $\mathrm{UC}=$ uniformity coefficient.

[b] For post-bioreactor woodchips: $n=2$, including one partial pseudo-replication, as described in the Methods section;

for post-bioreactor mixed shreds: $n=4$, including two pseudo-replications (“ \pm ” indicates standard deviation).

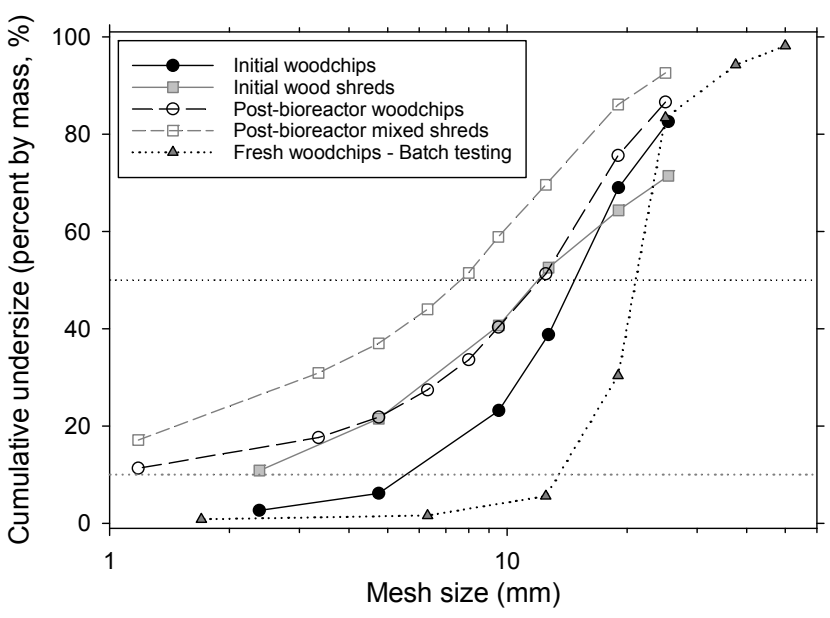

Figure 2. Particle size distribution of two initial wood media (woodchips and wood shreds in fig. 1; data adapted from Christianson et al., 2010), two post-bioreactor media (woodchips and mixed shreds), and fresh woodchips used in the batch test. Horizontal lines represent $D_{10}$ (effective particle size) and $D_{50}$ (median particle size).

tively, after more than nine years in an operational denitrifying bioreactor (table 1). While the initial $K_{\text {sat }}$ of the wood media was not determined, similar initially sized woodchips (i.e., approx. 10 to $15 \mathrm{~mm}$ ) have been reported to have $K_{\text {sat }}$ values ranging from approximately 2.7 to $8.1 \mathrm{~cm} \mathrm{~s}^{-1}$ (Cameron and Schipper, 2010; Chun et al., 2009; Feyereisen and Christianson, 2015).

The $\mathrm{D}_{50}$ values of the post-bioreactor woodchips and mixed shreds were 12.1 and $7.7 \mathrm{~mm}$, respectively (table 1), and the fraction of particles passing the smallest sieve size $(1.18 \mathrm{~mm})$ was $11.3 \%$ and $17.1 \%$, respectively, for the two media. While there could be no statistical comparison for the initial and post-bioreactor media due to potential mixing in the bioreactor, the particle sizes tended to be larger for the two initial media than for the two post-bioreactor media $\left(D_{50}=15.1\right.$ and $12.0 \mathrm{~mm}$ for initial woodchips and wood shreds, respectively; table 1, fig. 2). Moreover, the UC values were less for the initial media compared to the post-bioreactor media, indicating that the post-bioreactor media were more heterogeneous (e.g., size breakdown) than the media used to fill the bioreactor (table 1).

\section{Nutrient ANd Carbon Quality Properties}

Carbon concentrations were significantly greater for the post-bioreactor woodchips than for the post-bioreactor mixed shreds at $48.4 \% \pm 0.9 \%$ and $46.9 \% \pm 1.3 \%$, respectively (mean \pm standard deviation; $\mathrm{p}=0.04$ ), whereas $\mathrm{N}$ concentrations were significantly greater for the mixed shreds than for the woodchips $(1.06 \% \pm 0.03 \%$ and $0.77 \% \pm 0.04 \%$, respectively; $\mathrm{p}<0.001$; table 2 ). The resulting $\mathrm{C}: \mathrm{N}$ ratio was significantly greater for the post-bioreactor woodchips versus the mixed shreds ( $63 \pm 3.0$ vs. $44 \pm 2.1$, respectively; $p<$ 0.001 ). The distinct differences in the chemical composition of the two media evaluated here likely existed during installation, although this testing was not done with the fresh materials.

The percentage of lignin was greater for mixed shreds than for woodchips $(47 \% \pm 2.3 \%$ and $41 \% \pm 0.7 \%$, respectively), and the percentages of cellulose $(17 \% \pm 1.9 \%$ and $24 \% \pm 1.7 \%$, respectively) and hemicellulose $(14 \% \pm 1.5 \%$ and $22 \% \pm 2.6 \%$, respectively) were less (table 2 ). The LCI values for the woodchips and mixed shreds were 0.63 and 0.74 , respectively, which overlapped the range of 0.70 to 0.80 that has been identified as a point of stabilization for the degradation of organic matter (DeBusk and Reddy, 1998; Melillo et al., 1989).

\section{Nitrate Removal Batch Test}

The harvested woodchips resulted in significantly lower nitrate concentrations at the end of the $96 \mathrm{~h}$ batch test compared to the fresh woodchips regardless of the water matrix (fig. 3). The post-bioreactor woodchips achieved $44 \%$ and $65 \%$ average nitrate concentration reductions in DI and tile drainage water, respectively, compared to the fresh woodchips, which only achieved $17 \%$ and $21 \%$ reductions, respectively. Neither type of woodchip was inoculated during the batch test, although the post-bioreactor woodchips had obviously been exposed to conditions suitable to enhance denitrification during the bioreactor life. A similar non-inoculated batch test, performed with eight types of wood media, showed nitrate concentration reductions of approximately $40 \%$ at $96 \mathrm{~h}$ (initial and final nitrate concentrations of $25.0 \mathrm{mg} \mathrm{NO}-\mathrm{N} \mathrm{L}^{-1}$ and 14.2 to $15.6 \mathrm{mg} \mathrm{NO}_{3}-\mathrm{N} \mathrm{L}^{-1}$, respectively) for all but the "willow with leaves" and "cypress

Table 2. Carbon quality and lignocellulose index (LCI) of post-bioreactor woodchips and mixed shreds after nine years (standard deviations in parentheses; $n=6$ ). Within a column, means with the same letter are not significantly different at $\alpha=0.05$.

\begin{tabular}{cccccccc}
\hline $\begin{array}{c}\text { Post-Bioreactor } \\
\text { Media }\end{array}$ & $\begin{array}{c}\text { Carbon } \\
(\%)\end{array}$ & $\begin{array}{c}\text { Nitrogen } \\
(\%)\end{array}$ & $\begin{array}{c}\text { C:N } \\
\text { Ratio }\end{array}$ & $\begin{array}{c}\text { Lignin } \\
(\%)\end{array}$ & $\begin{array}{c}\text { Cellulose } \\
(\%)\end{array}$ & $\begin{array}{c}\text { Hemicellulose } \\
(\%)\end{array}$ & $\begin{array}{c}\text { LCI } \\
(\%)\end{array}$ \\
\hline Woodchips & $48.4(0.9) \mathrm{a}$ & $0.77(0.04) \mathrm{b}$ & $63(3.0) \mathrm{a}$ & $40.7(0.7) \mathrm{b}$ & $24.2(1.7) \mathrm{a}$ & $22.2(2.6) \mathrm{a}$ & $0.627(0.020) \mathrm{b}$ \\
Mixed shreds & $46.9(1.3) \mathrm{b}$ & $1.06(0.03) \mathrm{a}$ & $44(2.1) \mathrm{b}$ & $47.1(2.3) \mathrm{a}$ & $16.6(1.9) \mathrm{b}$ & $14.0(1.5) \mathrm{b}$ & $0.740(0.029) \mathrm{a}$ \\
\hline
\end{tabular}



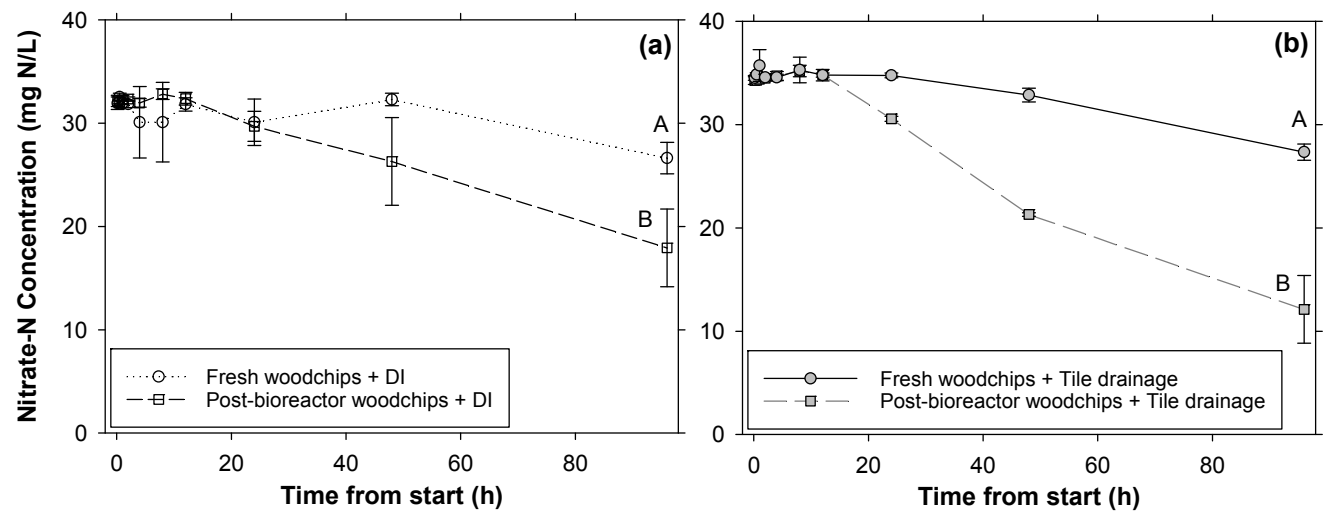

Figure 3. Nitrate-nitrogen concentrations during batch test of fresh and post-bioreactor woodchips in (a) deionized (DI) water and (b) tile drainage water. For the $96 \mathrm{~h}$ samples across both graphs, means followed by the same letter are not significantly different at $\alpha=0.05$.

Table 3. Mean nutrient concentrations from batch test of fresh and post-bioreactor woodchips (standard deviations in parentheses; $n=3$ ). Within a column, means with the same letter are not significantly different at $\alpha=0.05$.

\begin{tabular}{cccccc}
\hline \multirow{2}{*}{ Sampling Event } & Media & Water Matrix & $\begin{array}{c}\text { Carbon } \\
(\%)\end{array}$ & $\begin{array}{c}\text { Nitrogen } \\
(\%)\end{array}$ & $\begin{array}{c}\text { C:N } \\
\text { Ratio }\end{array}$ \\
\hline \multirow{2}{*}{ Initial $(t=0 \mathrm{~h})$} & Fresh woodchips & - & $48(0.4) \mathrm{a}$ & $0.22(0.02) \mathrm{b}$ & $215(19) \mathrm{a}$ \\
& Post-bioreactor woodchips & - & $44(2.9) \mathrm{ab}$ & $0.88(0.07) \mathrm{a}$ & $51(4) \mathrm{c}$ \\
\hline \multirow{2}{*}{ Final $(t=96 \mathrm{~h})$} & \multirow{2}{*}{ Fresh woodchips } & Deionized water & $48(1.4) \mathrm{a}$ & $0.31(0.02) \mathrm{b}$ & $153(15) \mathrm{b}$ \\
& & Tile drainage & $44(0.5) \mathrm{ab}$ & $0.27(0.06) \mathrm{b}$ & $169(46) \mathrm{ab}$ \\
\cline { 2 - 7 } & \multirow{2}{*}{ Post-bioreactor woodchips } & Deionized water & $38(4.8) \mathrm{b}$ & $0.87(0.06) \mathrm{a}$ & $44(7) \mathrm{c}$ \\
& & Tile drainage & $35(6.1) \mathrm{b}$ & $1.0(0.10) \mathrm{a}$ & $35(3) \mathrm{c}$ \\
\hline
\end{tabular}

without needles" treatments, which exhibited greater $\mathrm{N}$ removal ( $\geq 80 \%$ for both treatments) (Christianson et al., 2014).

Neither the $\mathrm{C}$ nor $\mathrm{N}$ concentrations of either wood media changed significantly over the batch test (table 3 ). The most notable difference was that the post-bioreactor woodchips had a significantly greater $\mathrm{N}$ content compared to the fresh woodchips, both initially and after the test (table $3 ; 0.87 \%$ to $1.0 \%$ for post-bioreactor woodchips, and $0.22 \%$ to $0.31 \%$ for fresh woodchips). When translated into $\mathrm{C}: \mathrm{N}$ ratios, the postbioreactor woodchips had very low ratios, both initially and at the end of the batch test (means ranging from 35 to 51), corroborating the results in table 2 . The $\mathrm{C}: \mathrm{N}$ ratio for the fresh woodchips declined significantly from 215 to 153 when DI water was used.

\section{Conservative Tracer Tests}

Incomplete capture of the full tracer curve in 2009 limited calculation of many quantitative tracer metrics for this test (fig. 4). However, the data that were captured indicated that the peak tracer concentration occurred no earlier than $11.5 \mathrm{~h}$ at the tracer test's flow rate (table 4$)$. The resulting hydraulic efficiency ( $\lambda$, the time to peak divided by HRT), which could be considered the minimum $\lambda$ in this case due to the limited data, was 2.2, given that the HRT was $5.2 \mathrm{~h}$ (assuming initial drainable porosity of 0.46 following Feyereisen and Christianson, 2015; table 4). In theory, a tracer test in an ideally performing plug flow reactor would peak at exactly one cumulative pore volume, meaning $\lambda=1.0$. If the assumption of total rather than drainable porosity is used in tracer calculations, the resulting hydraulic efficiency is still greater than 1.0 (e.g., assuming a total porosity of 0.70 yields $\lambda=1.45$ ).

The limited 2009 data also indicated that the tracer residence time, which should be considered a minimum possible

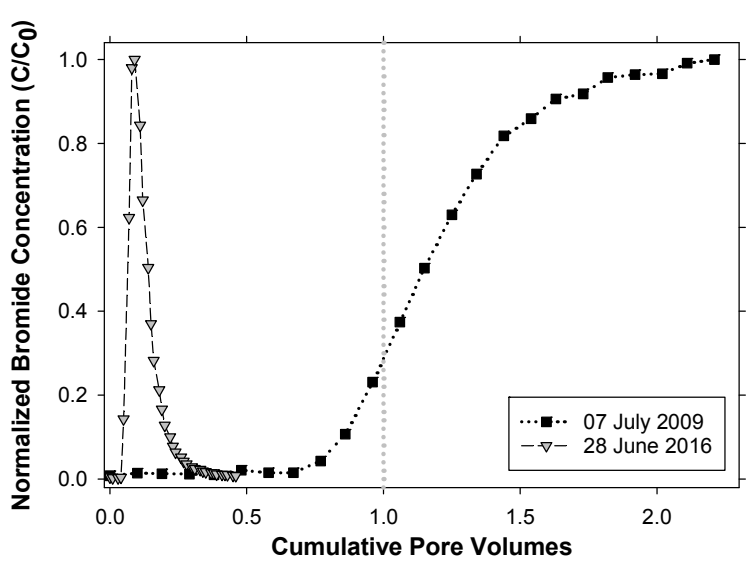

Figure 4. Tracer test results for Greene County, Iowa, denitrifying bioreactor in 2009 and 2016. Bromide concentrations were normalized by the highest detected value for each test $\left(\mathrm{C}_{0}\right)$, and time was normalized to cumulative pore volume. Vertical line indicates time of theoretically ideal tracer peak at cumulative pore volume of 1.0.

value for this test, was $8.7 \mathrm{~h}$, resulting in an effective volume ( $e$, the tracer residence time divided by the theoretical HRT) greater than 1.0. A tracer solution residing in the reactor longer than the theoretical HRT (i.e., $e>1.0$ ) indicates that the reactor is operating more effectively than its specific dimensions, which are used to calculate the HRT, would indicate.

Replacing the assumed $46 \%$ drainable porosity with $33 \%$ (table 1) to be more representative of conditions near the end of the design life, the theoretical HRT during the 2016 tracer

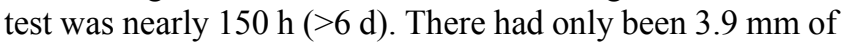
precipitation in the seven days prior to this test, compared to $32 \mathrm{~mm}$ in the week prior to the 2009 test, which likely contributed to the low drainage flow rate in the 2016 tracer test (the low 2016 drainage volume is discussed further in the 
Table 4. Tracer test metrics for Greene County, Iowa, bioreactor at 0.9 and 7.8 years after installation. Theoretical HRT $=$ drainable porosity $\times$ total bioreactor volume (as constructed) divided by daily bioreactor flow rate, effective volume $(e)=$ mean tracer residence time divided by theoretical HRT, and hydraulic efficiency $(\lambda)=$ time to tracer peak divided by theoretical HRT.

\begin{tabular}{|c|c|c|c|c|c|c|c|c|c|}
\hline \multirow{4}{*}{$\begin{array}{c}\text { Tracer } \\
\text { Test Date }\end{array}$} & \multirow{4}{*}{$\begin{array}{c}\text { Bioreactor } \\
\text { Age } \\
\text { (years) }\end{array}$} & \multirow{4}{*}{$\begin{array}{c}\text { Cumulative } \\
\text { Precipitation in } \\
\text { Previous } 7 \mathrm{~d} \\
(\mathrm{~mm})\end{array}$} & \multicolumn{7}{|c|}{ Mean Tracer } \\
\hline & & & Drainable & Flow & Theoretical & Residence & Effective & Time to & Hydraulic \\
\hline & & & Porosity ${ }^{[a]}$ & Rate & HRT & Time & Volume & Peak & Efficiency \\
\hline & & & $(\%)$ & $\left(\mathrm{L} \min ^{-1}\right)$ & (h) & (h) & $(e)$ & (h) & $(\lambda)$ \\
\hline 7 July 2009 & 0.9 & 32 & 46 & 52 & 5.2 & 8.7 & 1.7 & $11.5^{[\mathrm{b}]}$ & 2.2 \\
\hline 28 June 2016 & 7.8 & 3.9 & 33 & 1.3 & 150 & 19 & 0.13 & 14.0 & 0.09 \\
\hline
\end{tabular}

[a] Assumed 2009 value of 46\% following Feyereisen and Christianson (2015); 2016 value of 33\% from table 1.

[b] Minimum value based on limited data.

Discussion section). Regardless, there were notable decreases in effective volume $(0.13)$ and hydraulic efficiency (0.09) compared to the 2009 tracer test (table 4). The early peak in terms of cumulative pore volume (i.e., hydraulic efficiency much less than 1.0) was especially indicative that the bioreactor hydraulics had changed from 2009 (fig. 4).

\section{BIOREACTOR FLOW AND N REMOVAL}

More than $50 \%$ of the drainage flow was treated by the bioreactor during the initial monitoring periods (as reported by Christianson et al., 2012b), whereas only $6.1 \%$ of the drainage flow was treated during the 2016 monitoring period when the bioreactor was approximately eight years old (table 5). This small percentage of treated flow was related to the very low flow rates measured at the bioreactor outlet in 2016, which tended to be an order of magnitude less than for the earlier monitoring periods. For example, in figure 5a, when $100 \%$ of the daily flow was routed into the bioreactor, and thus the daily flow rate from the field equaled the bioreactor flow rate, the flow rates in 2016 (triangles; $<5 \mathrm{~L} \mathrm{~min}^{-1}$ ) were lower than the flow rates in 2009-2011 (circles; many $>10 \mathrm{~L} \mathrm{~min}^{-1}$ ). Bypass flow was also initiated at lower flow rates in 2016 versus 2009-2011 (fig. 5a). At a given range of flow rates, the bioreactor tended to exhibit lower nitrate-N concentration reductions in the later monitoring period compared to the earlier period (e.g., triangles tend to be lower than circles at a given flow rate in fig. $5 b$ ).

Iterative control structure (stop log) management was performed as decreased nitrate concentration reductions were observed over time. Field notes indicated that the outlet stop log settings were 18 and $30 \mathrm{~cm}$ in 2009 and 2016, respectively. The depth of the outlet stop logs was increased over time to hold more water back in the bioreactor (i.e., increased in situ retention time). Theoretically, this increased outlet depth decreased the head gradient across the bioreactor, which may have resulted in increased bypass flow at lower flow volumes, as was anecdotally observed on-site.
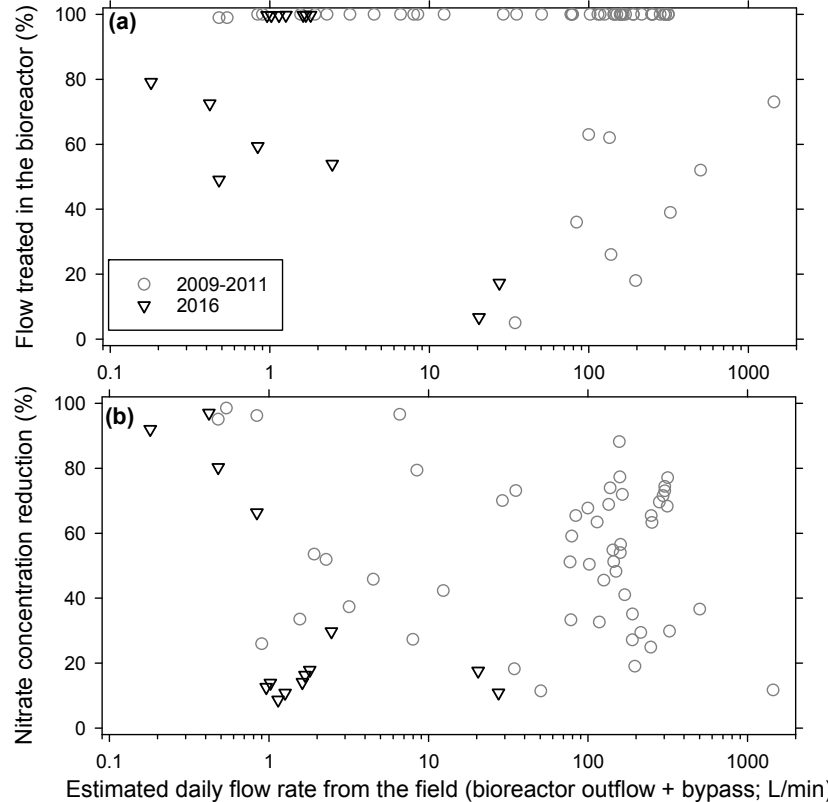

Figure 5. (a) Percent of flow treated in the bioreactor and (b) nitrate-N concentration reductions across the bioreactor for daily sample events in two monitoring period (2009-2011 and 2016) across a range of estimated total flow rates from the field (note that $x$-axis is log scale).

\section{DISCUSSION \\ Physical Changes in Media Had \\ Multiple CAuSes ANd EfFects}

The $K_{\text {sat }}$ values measured for the post-bioreactor woodchips and mixed shreds $\left(4.2\right.$ and $3.1 \mathrm{~cm} \mathrm{~s}^{-1}$, respectively; table 1) were within the range of reported values for woodchips, albeit at the low end (2.4 to $12.2 \mathrm{~cm} \mathrm{~s}^{-1}$; Burbery et al., 2014; Cameron and Schipper, 2010; Chun et al., 2009; Feyereisen and Christianson, 2015; Ghane et al., 2014). Although the initial $K_{\text {sat }}$ of the wood media was not measured, similar-size woodchips have typically been reported to have initial $K_{\text {sat }}$ values greater than that determined here for the post-bioreactor media (e.g., $8.1 \mathrm{~cm} \mathrm{~s}^{-1}$ for fresh $15 \mathrm{~mm}$

Table 5. Basic water balance for subsurface drainage at Greene County, Iowa, bioreactor for two monitoring periods (2009-2011 and 2016) roughly by water years. Some of the 2009-2011 data were adapted from Christianson et al. (2012b). Average annual long-term precipitation at the site was approximately $870 \mathrm{~mm}$.

\begin{tabular}{cccccc}
\hline & $\begin{array}{c}\text { Precipitation } \\
\text { for Period } \\
\text { Period }\end{array}$ & $\begin{array}{c}\text { Drainage } \\
(\mathrm{mm})\end{array}$ & $\begin{array}{c}\text { Percent of Precipitation } \\
\text { Occurring as Drainage } \\
(\%)\end{array}$ & $\begin{array}{c}\text { Bioreactor } \\
\text { Treated Flow } \\
(\mathrm{mm})\end{array}$ & $\begin{array}{c}\text { Percent of } \\
\text { Drainage Treated } \\
(\%)\end{array}$ \\
\hline 1 Jan. 2009 to 30 Sept. 2009 & 650 & $390^{[b]}$ & 60 & $210^{[\mathrm{b}]}$ & $53^{[\mathrm{b}]}$ \\
1 Oct. 2009 to 30 Sept. 2010 & 1200 & $650^{[\mathrm{b}]}$ & 54 & $450^{[\mathrm{b}]}$ & $68^{[\mathrm{b}]}$ \\
1 Oct. 2010 to 29 July 2011 & 530 & $35^{[\mathrm{b}]}$ & 5.8 & 27 & $55^{[\mathrm{b}]}$ \\
\hline 29 Mar. 2016 to 4 Oct. 2016 & 780 & 27 & 3.5 & 2 & 6.1 \\
\hline
\end{tabular}

[a] Calculated as bioreactor outflow plus bypass flow.

[b] Previously reported by Christianson et al. (2012b). 
woodchips; Cameron and Schipper, 2010). These results were consistent with previous shorter-term studies documenting reductions in $K_{\text {sat }}$ over approximately two years (e.g., Cameron and Schipper, 2010; Ghane et al., 2014). Importantly, because two media types with different particle sizes were used in this bioreactor, the media with the lower $K_{\text {sat }}$ essentially throttled the flow.

The likely, yet assumed, reduction in $K_{\text {sat }}$ was consistent with the reduction in wood media particle sizes over the nine years of bioreactor operation (fig. 2). It is well established that smaller particle sizes have lower $K_{\text {sat }}$ values relative to larger media. In addition to the particle size distribution shifting downward due to degradation of the woody media over time, it is also likely that the distribution shifted because of transport of silt and clay sediment into the bioreactor. More than $10 \%$ of the excavated media, for both the woodchips and mixed shreds, fell under the particle size range of $1.18 \mathrm{~mm}$. The initial nutrient analysis with very high ash contents confirmed that these small particles were inorganic and were likely derived from soil minerals. The low drainable porosity values $(32 \%$ to $33 \%$; table 1$)$ compared to other studies (e.g., 37\% to $46 \%$; Feyereisen and Christianson, 2015; Ghane et al., 2016) are further evidence of the negative impact of small particles and sediment on $K_{\text {sat. }}$. Siltation was likely more intense near the inlet, as documented in other studies (e.g., Robertson et al., 2018). Flow restriction caused by this inlet siltation would not have been reflected in the permeameter data, which was based on media harvested nearer the middle and outlet. This possible impact is significant, again, because of a flow throttling effect.

This bioreactor was installed on a subsurface drainage system with a surface intake (Christianson et al., 2012b), which corroborates the potential for a relatively greater sediment load to enter the bioreactor. This surface intake may also account for the relatively high percentage of precipitation occurring as drainage during several of the early monitoring periods (54\% to $60 \%$ from table 5 vs. $18 \%$ to $27 \%$ in a review by Christianson and Harmel, 2015). For this reason, the USDA-NRCS Conservation Practice Standard for bioreactors discourages placement of denitrifying bioreactors on drainage systems with surface intakes (USDA, 2015). However, with an operational life of nine years, it could be argued that, given this caveat, some drainage systems with surface intakes could be suitable for bioreactor installation.

This study was limited, in part, by the lack of quantification of the initial physical properties of the wood media at the time of bioreactor installation. Long-term studies documenting biofilm formation and flushing, siltation, wood decay, and additional water chemistry parameters (e.g., alkalinity; Jones and Kult, 2016) across the life of a bioreactor would better inform threshold values for woodchip recharge and provide guidance on assessing the effectiveness of aging bioreactors. This type of study requires administrative and logistical foresight, well-established relationships with field partners, and funders willing to make long-standing commitments to bioreactor science and engineering.

\section{Impacts of Media Physical Changes MaY HaVe BeEN EXACERBATED by Preferential Flow}

It is possible that the bioreactor's relatively low length:width ratio $(\mathrm{L}: \mathrm{W}=2: 1)$ contributed to the relatively high hydraulic efficiency and effective volume, which were both greater than 1.0 early in the bioreactor's life (2.2 and 1.7, respectively; table 4). Similar findings were reported by Dougherty (2018), who performed three tracer tests on another relatively wide tile drainage bioreactor with dimensions of $17 \mathrm{~m} \mathrm{~L} \times 11 \mathrm{~m} \mathrm{~W}(\mathrm{~L}: \mathrm{W}=1.5: 1)$. Those tests resulted in hydraulic efficiencies of 0.82 to 1.52 and effective volumes of 1.26 to 1.73 . Other full-size bioreactors with $\mathrm{L}: \mathrm{W}$ ratios of at least $4: 1$ have had hydraulic efficiencies and effective volumes of generally less than 1.0 and sometimes much less than that value (Christianson et al., 2013; Dougherty, 2018; Hoover et al., 2017). The current federal design guidance encourages bioreactor $\mathrm{L}: \mathrm{W}$ ratios of at least $4: 1$, unless a multiple distribution manifold is used (USDA, 2015). Woodchip bioreactor technology could still be considered relatively young, meaning that additional design options have yet to be explored.

The high initial tracer test metrics made the decrease over time especially notable. The decrease in hydraulic efficiency from 2.2 in 2009 to 0.09 in 2016 spanned the range reported by Persson et al. (1999), who defined hydraulic efficiency of $>0.75$ as good performance and $<0.50$ as poor performance. The tracer peaked at a relatively similar time during both tests (14.0 vs. $11.5 \mathrm{~h}$; table 4 ), although this translated into very different cumulative pore volumes, that is, very different hydraulic efficiencies. The 2016 tracer solution exited the bioreactor much earlier than expected (fig. 4), given the very low flow rate and high theoretical HRT $(150 \mathrm{~h})$. The early tracer exit in the 2016 test combined with the low effective volume ( $e=0.13$, table 4 ; i.e., only $13 \%$ of the reactor was being used) was an indication of potential short-circuiting. It is plausible that preferential flow paths developed over time, especially as the particle size decreased and sediment accumulation increased.

The concept of flow restriction and development of preferential flow paths was supported by the notable decrease in the measured bioreactor outflow rates when comparing the 2009-2011 and 2016 monitoring periods (fig. 5). Drainage depths that were only $5.8 \%$ and $3.5 \%$ of precipitation for the October 2010 to July 2011 and 2016 monitoring periods (table 5) were low compared to a survey of the literature on North American subsurface drainage, which tends to be between $18 \%$ and $27 \%$ of the annual precipitation depth (Christianson and Harmel, 2015). The $530 \mathrm{~mm}$ of precipitation for the October 2010 to July 2011 period was dry compared to the long-term average of $690 \mathrm{~mm}$ for those ten months, which may have partially accounted for only $5.8 \%$ of the precipitation occurring as drainage during that period. However, the $780 \mathrm{~mm}$ of precipitation during the 2016 monitoring period was similar to the long-term annual expected precipitation for those months $(740 \mathrm{~mm})$. The very low estimated drainage volume from the field and the corresponding $3.5 \%$ of precipitation occurring as drainage were possibly related to an underestimation of the water entering the bioreactor. Total drainage flow from the field was not measured 
individually but rather was summed from the bioreactor outflow plus the bypass flow (see the Methods section). If drainage water from the field entered the inlet control structure but seeped out of the unlined bioreactor, it would be missing from the water balance because it would not have flowed over either control structure's stop-log weir.

\section{Carbon Quality Declined but Media STILL SUPPORTED N REMOVAL}

The relatively low C:N ratio of the post-bioreactor media corroborated other studies documenting the consumption of $\mathrm{C}$, relative increase in $\mathrm{N}$ concentration, and corresponding decrease in $\mathrm{C}: \mathrm{N}$ that wood media in bioreactors experience over time (Christianson et al., 2016; Feyereisen et al., 2016; Ghane et al., 2018). Woodchip C and $\mathrm{N}$ analysis may be relatively easy for a land owner to perform on an aging bioreactor, as many soil sample labs can perform these tests on woodchips. Thus, it may be tempting to use the $\mathrm{C}: \mathrm{N}$ ratio as an easy measure to assess the need for woodchip replacement. However, a low C:N ratio does not inherently imply an exhaustion of $\mathrm{C}$ or unavailability of $\mathrm{C}$ for denitrification. The batch test demonstrated that the wood media were still capable of supporting nitrate removal despite their low C:N ratios (fig. 3, table 3). Moreover, many materials with low $\mathrm{C}: \mathrm{N}$ ratios, such as yard waste (C:N 77; Christianson et al., 2012a) and corn cobs (C:N 83; Feyereisen et al., 2016) contain $\mathrm{C}$ that is more readily available for denitrification and have greater $\mathrm{N}$ removal potential than woodchips, but also have shorter bioreactor lifespans and leach more C (Cameron and Schipper, 2010; Feyereisen et al., 2016). The results of the batch test (post-bioreactor versus fresh woodchips achieved $\geq 44 \%$ versus $\leq 21 \%$ nitrate removal, respectively) were likely influenced by the lack of inoculation of the fresh woodchips.

A relatively high LCI indicates a decline in the quality of remaining available $C$. The LCIs of the media $(0.63$ and 0.74 ) were nearing the range of decomposition stabilization (i.e., LCI $\approx 0.70$ to 0.80; DeBusk and Reddy, 1998; Melillo et al., 1989). Lignocellulose indices at and greater than this range indicate that the material is highly recalcitrant to further breakdown; many soils have LCIs of 0.70 to 0.83 (Melillo et al., 1989). This decline in C quality in the bioreactor was corroborated by the relatively lower nitrate-N concentration reductions from the 2016 versus 2009-2011 monitoring periods when compared at a given range of flow rates (fig. 5). While LCIs were not determined for the original media, the post-bioreactor values were likely an increase over the initial values, as the reported LCIs for fresh wood media are generally around 0.20 to 0.25 (Christianson et al., 2016; Schmidt and Clark, 2012), with Feyereisen et al. (2016) reporting an initial value as high as 0.45 , which was still lower than the final values reported here. The LCIs in this study were also greater than those reported by Ghane et al. (2018) for woodchips collected from a bioreactor after four years (range of 0.47 to 0.57 ). The media were influenced by both aerobic and saturated anaerobic conditions due to seasonally fluctuating drainage flow. Additional research is needed on the effects on denitrification performance of decreasing $\mathrm{C}: \mathrm{N}$ ratio and increasing LCI over time.

\section{CONClusions}

Changes in the physical and chemical properties of wood media over nine years of denitrifying bioreactor operation corroborated the reductions in performance assessed with field testing. Saturated hydraulic conductivity and particle size distribution are closely linked. Woodchip degradation led to decreased particle size ranges; this change, along with sedimentation from the drainage system, reduced pore sizes in the bed and likely reduced bioreactor conductivities over time. Possible flow restriction may have led to the development of preferential flow paths through the bioreactor, which were indicated by the low bioreactor outflow rates (i.e., reduced permeability) and reduced hydraulic efficiency (i.e., early tracer testing peak) when the bioreactor was approximately eight years old.

Changes in the hydraulics over time can result in reduced nitrate removal, as preferential flow paths can lead to reduced reactor volume utilization (i.e., low effective volume), essentially short-circuiting conditions adequate for denitrification. Relatively decreased nitrate-N concentration reductions in the bioreactor over time were further supported by a decrease in the media $\mathrm{C}: \mathrm{N}$ ratio and a decline in $\mathrm{C}$ quality indicated by the LCI. Even so, the batch test demonstrated the robustness of wood as a $\mathrm{C}$ source for denitrification after nine years. These media property changes and linked impacts resulted in the need to recharge this bioreactor after nine years. Modified flow properties, such as flow restriction and preferential flow paths, may be a more important consideration at the end of bioreactor life than the denitrification rates the system can sustain.

\section{ACKNOWLEDGEMENTS}

This work was partially funded by USDA-NIFA Hatch Project ILLU-802-925, Agriculture's Clean Water Alliance, and the soybean checkoff through the Iowa Soybean Association. Thanks to undergraduate students J. Roh for helping with the batch testing, J. Mrozek and K. Holmberg for assistance with the hydraulic conductivity testing, and T. Schumacher and S. Okkema for sieve analyses and $\mathrm{C} / \mathrm{N}$ testing.

\section{REFERENCES}

Addy, K., Gold, A. J., Christianson, L. E., David, M. B., Schipper, L. A., \& Ratigan, N. A. (2016). Denitrifying bioreactors for nitrate removal: A meta-analysis. J. Environ. Qual., 45(3), 873881. https://doi.org/10.2134/jeq2015.07.0399

Burbery, L. F., Abraham, P., \& Afrit, B. (2014). Determining the hydraulic properties of wood/gravel mixtures for use in denitrifying walls. J. Hydrol. (New Zealand), 53(1), 1-21.

Cameron, S. G., \& Schipper, L. A. (2010). Nitrate removal and hydraulic performance of organic carbon for use in denitrification beds. Ecol. Eng., 36(11), 1588-1595. https://doi.org/10.1016/j.ecoleng.2010.03.010

Christianson, L. E., \& Harmel, R. D. (2015). The MANAGE drain load database: Review and compilation of more than fifty years of North American drainage nutrient studies. Agric. Water Mgmt., 159, 277-289. https://doi.org/10.1016/j.agwat.2015.06.021

Christianson, L. E., \& Schipper, L. A. (2016). Moving denitrifying bioreactors beyond proof of concept: Introduction to the special 
section. J. Environ. Qual., 45(3), 757-761. https://doi.org/10.2134/jeq2016.01.0013

Christianson, L. E., Hanly, J. A., \& Hedley, M. J. (2014). Suitability of three wood species for denitrification bioreactor fill. ASABE Paper No. 141896470. St. Joseph, MI: ASABE. https://doi.org/10.13031/aim.20141896470

Christianson, L. E., Hoover, N., Bhandari, A., \& Helmers, M. J. (2012a). Technical note: The potential of municipal yard waste to be denitrification bioreactor fill. Appl. Eng. Agric., 28(6), 853859. https://doi.org/10.13031/2013.42478

Christianson, L. E., Lepine, C., Sharrer, K. L., \& Summerfelt, S. T. (2016). Denitrifying bioreactor clogging potential during wastewater treatment. Water Res., 105, 147-156. https://doi.org/10.1016/j.watres.2016.08.067

Christianson, L., Bhandari, A., Helmers, M., Kult, K., Sutphin, T., \& Wolf, R. (2012b). Performance evaluation of four field-scale agricultural drainage denitrification bioreactors in Iowa. Trans. ASABE, 55(6), 2163-2174. https://doi.org/10.13031/2013.42508

Christianson, L., Castello, A., Christianson, R., Helmers, M., \& Bhandari, A. (2010). Technical note: Hydraulic property determination of denitrifying bioreactor fill media. Appl. Eng. Agric., 26(5), 849-854. https://doi.org/10.13031/2013.34946

Christianson, L., Helmers, M., Bhandari, A., \& Moorman, T. (2013). Internal hydraulics of an agricultural drainage denitrification bioreactor. Ecol. Eng., 52, 298-307. https://doi.org/10.1016/j.ecoleng.2012.11.001

Chun, J. A., Cooke, R. A., Eheart, J. W., \& Kang, M. S. (2009). Estimation of flow and transport parameters for woodchip-based bioreactors: I. laboratory-scale bioreactor. Biosyst. Eng., 104(3), 384-395. https://doi.org/10.1016/j.biosystemseng.2009.06.021

DeBusk, W. F., \& Reddy, K. R. (1998). Turnover of detrital organic carbon in a nutrient-impacted everglades marsh. SSSA J., 62(5), 1460-1468. 10.2136/sssaj1998.03615995006200050045x

Dougherty, H. (2018). Hydraulic evaluation of a denitrifying bioreactor with baffles. MS thesis. Urbana, IL: University of Illinois, Department of Crop Sciences.

Feyereisen, G. W., \& Christianson, L. E. (2015). Hydraulic flow characteristics of agricultural residues for denitrifying bioreactor media. Appl. Eng. Agric., 31(1), 89-96. https://doi.org/10.13031/aea.31.10552

Feyereisen, G. W., Moorman, T. B., Christianson, L. E., Venterea, R. T., Coulter, J. A., \& Tschirner, U. W. (2016). Performance of agricultural residue media in laboratory denitrifying bioreactors at low temperatures. J. Environ. Qual., 45(3), 779-787. https://doi.org/10.2134/jeq2015.07.0407

Ghane, E., Fausey, N. R., \& Brown, L. C. (2014). Non-Darcy flow of water through woodchip media. J. Hydrol., 519, 3400-3409. https://doi.org/10.1016/j.jhydrol.2014.09.065

Ghane, E., Feyereisen, G. W., \& Rosen, C. J. (2016). Non-linear hydraulic properties of woodchips necessary to design denitrification beds. J. Hydrol., 542, 463-473. https://doi.org/10.1016/j.jhydrol.2016.09.021

Ghane, E., Feyereisen, G. W., Rosen, C. J., \& Tschirner, U. W. (2018). Carbon quality of four-year-old woodchips in a denitrification bed treating agricultural drainage water. Trans. ASABE, 61(3), 995-1000. https://doi.org/10.13031/trans.12642

Hertzberger, A., Pittelkow, C. M., Harmel, R. D., \& Christianson, L. E. (2019). The MANAGE drain concentration database: A new tool compiling North American drainage nutrient concentrations. Agric. Water Mgmt., 216, 113-117. https://doi.org/10.1016/j.agwat.2019.01.021
Hoover, N. L., Soupir, M. L., VanDePol, R. D., Goode, T. R., \& Law, J. Y. (2017). Pilot-scale denitrification bioreactors for replicated field research. Appl. Eng. Agric., 33(1), 83-90. https://doi.org/10.13031/aea.11736

Iowa. (2019). Iowa Environmental Mesonet: NWS cooperative data, Jefferson station. Ames, IA: Iowa State University. Retrieved from https://mesonet.agron.iastate.edu/COOP/.

Jones, C. S., \& Kult, K. J. (2016). Use alkalinity monitoring to optimize bioreactor performance. J. Environ. Qual., 45(3), 855865. https://doi.org/10.2134/jeq2015.06.0309

Martin, A. R., Gezahegn, S., \& Thomas, S. C. (2015). Variation in carbon and nitrogen concentration among major woody tissue types in temperate trees. Canadian J. Forest Res., 45(6), 744757. https://doi.org/10.1139/cjfr-2015-0024

Melillo, J. M., Aber, J. D., Linkins, A. E., Ricca, A., Fry, B., \& Nadelhoffer, K. J. (1989). Carbon and nitrogen dynamics along the decay continuum: Plant litter to soil organic matter. Plant Soil, 115(2), 189-198. https://doi.org/10.1007/BF02202587

Moorman, T. B., Parkin, T. B., Kaspar, T. C., \& Jaynes, D. B. (2010). Denitrification activity, wood loss, and $\mathrm{N}_{2} \mathrm{O}$ emissions over nine years from a wood chip bioreactor. Ecol. Eng., 36(11), 1567-1574. https://doi.org/10.1016/j.ecoleng.2010.03.012

Persson, J., Somes, N. L. G., \& Wong, T. H. F. (1999). Hydraulic efficiency of constructed wetlands and ponds. Water Sci. Tech., 40(3), 291-300. https://doi.org/10.2166/wst.1999.0174

Robertson, W. D. (2010). Nitrate removal rates in woodchip media of varying age. Ecol. Eng., 36(11), 1581-1587. https://doi.org/10.1016/j.ecoleng.2010.01.008

Robertson, W. D., \& Cherry, J. A. (1995). In situ denitrification of septic-system nitrate using reactive porous media barriers: Field trials. Groundwater, 33(1), 99-111. https://doi.org/10.1111/j.1745-6584.1995.tb00266.x

Robertson, W. D., Feng, D., Kobylinski, S., Finnigan, D. S., Merkley, C., \& Schiff, S. L. (2018). Low-cost media can filter particulate phosphorus from turbid stream water under short retention times. Ecol. Eng., 123, 95-102. https://doi.org/10.1016/j.ecoleng.2018.08.015

Roser, M. B., Feyereisen, G. W., Spokas, K. A., Mulla, D. J., Strock, J. S., \& Gutknecht, J. (2018). Carbon dosing increases nitrate removal rates in denitrifying bioreactors at lowtemperature high-flow conditions. J. Environ. Qual., 47(4), 856864. https://doi.org/10.2134/jeq2018.02.0082

Schmidt, C. A., \& Clark, M. W. (2012). Efficacy of a denitrification wall to treat continuously high nitrate loads. Ecol. Eng., 42, 203211. https://doi.org/10.1016/j.ecoleng.2012.02.006

Sluiter, A., Hames, B., Ruiz, R., Scarlata, C., Sluiter, J., Templeton, D., \& Crocker, D. (2012). Determination of structural carbohydrates and lignin in biomass. Laboratory Analytical Procedure NREL/TP-510-42618. Golden, CO: National Renewable Energy Laboratory.

Tchobanoglus, G., Burton, F., \& Stensel, H. D. (2003). Wastewater engineering: Treatment and reuse (4th ed.). London, UK: McGraw-Hill.

Thackston, E. L., Shields Jr., F. D., \& Schroeder, P. R. (1987). Residence time distributions of shallow basins. J. Environ. Eng., 113(6), 1319-1332. https://doi.org/10.1061/(ASCE)07339372(1987)113:6(1319)

USDA. (2015). Conservation practice standard: Denitrifying bioreactor, Code 605 (605-CPS-1). Washington, DC: USDA Natural Resources Conservation Service. 